\title{
Modelling equilibrium data for manganese(II) sorption onto manganese dioxide modified chalcedonite using the non-linear regression method
}

\author{
MAGDALENA M. MICHEL, LIDIA KIEDRYŃSKA \\ Department of Civil Engineering, Warsaw University of Life Sciences - SGGW
}

\begin{abstract}
Modelling equilibrium data for manganese(II) sorption onto manganese oxide modified chalcedonite using the non-linear regression method. Manganese dioxide is characterized by the acidic type of surface and high value of negative surface charge. It shows sorption and oxidation properties to such pollutants as heavy metals, radionuclides, arsenate(III), iodide. In the water conditioning technology it is used to modify various materials, including chalcedonite, which was the subject of the research presented in this paper. The manganese(II) equilibrium sorption was modeled using the non-linear regression method and basing on the Langmuir, Freundlich, Redlich-Peterson as well as pseudoLangmuir isotherm equations. The determination of the isotherm equations parameters was run in two ways: by the minimization of the sum of the squared errors (SSE) as well as the minimization of the average relative error (ARE). The experimental data was best described in the Langmuir's isotherm equation, with the determination coefficient $r^{2}=0.916$. The calculated parameters of the equation equaled: $q_{m}=1.07 \mathrm{mg} / \mathrm{g}$ and $b=1.55 \mathrm{~L} /$ $/ \mathrm{mg}$. The three-parameter equations of RedlichPeterson and pseudo-Langmuir, assuming the possibility of multilayer sorption, came down to the Langmuir's equation. It serves as proof of monolayer sorption of manganese(II) onto manganese dioxide modified chalcedonite.
\end{abstract}

Key words: sorption, manganese, manganese dioxide, modified chalcedonite, the non-linear regression method.

\section{INTRODUCTION}

The underground water, compared with the surface water, is characterized by more stable composition, lower pollution content and higher sanitary stability (Kowal and Świderska-Bróż 2009). For these reasons, it is more preferred in producing drinking water. A commonly occurring additive in the underground water is i.a. manganese(II), which does not constitute a hazard for human health, but must be removed from water for economic and aesthetic reasons. The highest concentration of manganese(II) in potable water in Poland is $0.05 \mathrm{mg} / \mathrm{l}$, according to the order of the Ministry of Health from 20th April 2010 (Gazeta Prawna 72, pos. 466), which introduces recommendations stated in the European Commission Directive 98/83/EC, concerning the quality of potable water. The data of ordinary underground water land monitoring run by the State Inspection of Environmental Protection show that the highest acceptable manganese(II) concentration is exceeded in 55\% of underground water intakes (Świątczak et al. 2008). In numerous cases the highest acceptable manganese(II) concentration is exceeded in the distribution network 
water, especially in small water intakes (Świątczak et al. 2008).

One of the most popular methods of demanganization of the underground water is filtration through filters with a surface covered by manganese dioxide. It can be: natural manganese dioxide coated sand, i.e. quartz sand naturally covered by the oxide due to persistent filtration of water containing manganese(II); catalytic beds containing pyrolusite $\left(\beta-\mathrm{MnO}_{2}\right)$, which do not require regeneration; chemically active beds with catalytic properties, requiring regeneration by an oxidant. The mechanism of removing manganese(II) from water onto manganese dioxide is complicated and involves the rapid process of ion sorption, which is followed by the process of slow oxidation of ions (Olańczuk-Neyman 2001).

The manganese dioxide shows slight amphoteric features and especially active catalytic features, connected to the capability of giving up oxygen (Bielański 2004). The manganese dioxide can occur in more than ten natural and synthetic polymorphs which assume an amorphic or crystalline form, with a tunnel or layered structure (Fritsch et al. 1997; Feng et al. 1999). The surface of $\mathrm{MnO}_{2}$ has an acidic character and its $\mathrm{pH}_{\mathrm{pzc}}$ is equal between 1.5 and $5.0 \mathrm{of} \mathrm{pH}$, depending on structure and age (Murray 1974), hence in water solutions of $\mathrm{pH}$ higher than $\mathrm{pH}_{\mathrm{pzc}}$ the surface charge of dioxide is negative, which favors metal sorption (Lee et al. 2004). The value of the surface charge of $\mathrm{MnO}_{2}$ is high, hence this dioxide has a higher ability to clean water from metals than other oxides (like e.g. $\mathrm{SiO}_{2}, \mathrm{TiO}_{2}$, $\mathrm{Al}_{2} \mathrm{O}_{3}$ i FeOOH, Al-Degs et al. 2001).

A lot of research was conducted on the use of powdery manganese dioxide
- it was successfully used to clean water solutions from heavy metals (Kanungo et al. 2004a; Kanungo et al. 2004b; Tripathy et al. 2006), radionuclides (Koulouris 1995; Raje and Swain 2002) as well as arsenate(III) (Driehaus et al. 1995; Dias et al. 2008) and iodide (Allard et al. 2009). Also, various materials are impregnated by manganese dioxide and then successfully used to remove dissolved solids from water solutions. There are mainly: zeolite (Anielak 2006; Han et al. 2007), diatomite (Al-Degs et al. 2000; Al-Degs et al. 2001; Piech 2007), chalcedonite (Michel 2008; Michel et al. 2008; Michel 2009), montmorillonite (Boonfueng et al. 2005), quartz sand ( $\mathrm{Hu}$ et al. 2004; Lee et al. 2004; Kowal and Świderska-Bróż 2009), carbon nanotubes (Ma et al. 2007), aluminum oxide (Maliyekkal et al. 2006) as well as polymer fibers (Moor and Reid 1973; Su et al. 2009). The chalcedonite surface modification with the use of various impregnation techniques leads to the creation of chemically active materials, effective in the water demanganization process (Michel 2008; Michel et al. 2008; Michel 2009).

The aim of the paper is to characterize the process of manganese sorption onto manganese dioxide modified chalcedonite by adjusting non-linear equations of sorption isotherms to experimental data.

\section{MATERIAL AND METHODS}

\section{Sample preparation}

The chalcedonite samples were obtained from "Teofilów" deposits, located in Poland in the region of Tomaszów Mazowiecki and Nowe Miasto. Chalcedonite is a siliceous sedimentary rock and its chemical composition is given in literature 
(Michel 2011; Ratajczak and Wyszomirski 1991). Chalcedonite sand used in the studies consisted of grains of a diameter of $0.8-1.25 \mathrm{~mm}$. The modification was accomplished by the precipitation of manganese(IV) oxide in direct contact with the surface of the mineral carrier and binding with this surface. $100 \mathrm{~g}$ of chalcedonite was immersed in $20 \%$ solution of manganese(II) sulfate. The chalcedonite was then placed in $250 \mathrm{ml}$ of $5 \%$ potassium permanganate to precipitate the manganese dioxide. Next, the sample was washed in distilled water, dried in an oven at $100^{\circ} \mathrm{C}$ and then the modification procedure was repeated.

Chalcedonite grains were coated by amorphous manganese dioxide. Its physical characteristics, determined by the nitrogen adsorption isotherm technique at $77.4 \mathrm{~K}$, are: specific surface area 9.88 $\mathrm{m}^{2} / \mathrm{g}$, total pore volume $0.030 \mathrm{~cm}^{3} / \mathrm{g}$ (Michel 2008). The manganese dioxide modified chalcedonite will be referred to by MDMC.

\section{Batch experiment}

Sorption experiments were carried out by shaking out chalcedonite samples of various mass $(0.1-1.0 \mathrm{~g})$ with $100 \mathrm{ml}$ of aqueous solution of manganese(II) chloride $\left(\mathrm{MnCl}_{2}\right)$ of desired concentrations 1.0 and $5.0 \mathrm{mg} \mathrm{Mn} / \mathrm{L}$. Sorption isotherms were made for the solution at $\mathrm{pH} 6.0$ and at $283 \mathrm{~K}$. The time of reaction was $3 \mathrm{~h}$. Manganese(II) ion concentration in sorptives before and after sorption was determined using Atomic Absorption Spectrophotometer (PG Instruments).

The amount of manganese sorption at equilibrium $q_{e}(\mathrm{mg} / \mathrm{g})$, was calculated using the equation:

$$
q_{e}=\frac{\left(C_{0}-C_{e}\right) V}{m}
$$

where $C_{0}$ and $C_{e}(\mathrm{mg} / \mathrm{L})$ are respectively initial and equilibrium concentrations of manganese(II) ion in solution, $m$ is the mass of used MDMC $(\mathrm{g})$ and $V$ is the volume of the solution (L).

\section{Data treatment}

To model the equilibrium sorption data, there were examined the Langmuir (Langmuir 1916), Freundlich (Freundlich 1906), Redlich-Peterson (Redlich and Peterson 1959) and pseudo-Langmuir (Hu et al. 2004) isotherms. They are given, respectively, by Eqs. (2-5):

$$
\begin{aligned}
& q_{e}=\frac{q_{m} b C_{e}}{1+b C_{e}} \\
& q_{e}=K_{F} C_{e}^{\frac{1}{n}} \\
& q_{e}=\frac{A C_{e}}{1+B C_{e}^{g}}
\end{aligned}
$$

$$
q_{e}=\frac{q_{m} b_{1} C_{e}}{\left(1-b_{2} C_{e}\right)\left[1+\left(b_{1}-b_{2}\right) C_{e}\right]}
$$

where $q_{m}, b, K_{F}, n, A, B, g, b_{1}$ and $b_{2}$ are constants of isotherms. A trial-and-error procedure was used for the non-linear regression method using the solver add-in with Microsoft spreadsheet, Microsoft Excel. Two ways were used to adjust the equation parameters: the minimization of the sum of squared errors (SSE) and the minimization of the average relative error (ARE). The best fit of the isotherm equations to the experimental data was tested using the determination coefficient $r^{2}$. 


\section{RESULTS AND DISCUSSION}

The results of studies on sorption of manganese(II) on the MDMC are presented in Tables 1 and 2 as well as Figures 1 and 2. For the fitting of the isotherms model to experimental equilibrium data the non-linear regression method was used. As it was reported, it is a more complex mathematical method to obtain isotherm parameters, because in non-linear equations error structures are the same when the best-fitting isotherms are compared (Ho et al. 2005; Ho 2006; Salarirad and Behnamfard 2011). The best fit of the isotherms to the experimental data was obtained for the SSE method with the highest determination coefficient $r^{2}$. This was the case when all of the sorption isotherm equations were considered. Using the aforementioned methods (SSE and ARE), the obtained values of isotherm coefficients are slightly different. It is connected to different run of functions describing the experimental data, which is presented on Figs 1 and 2. Therefore, in the further part of the paper, the isotherm coefficients calculated with the SSE method will be analyzed.

The comparison of the two-parameter models of sorption isotherms (Tab. 1) shows that the experimental data is better

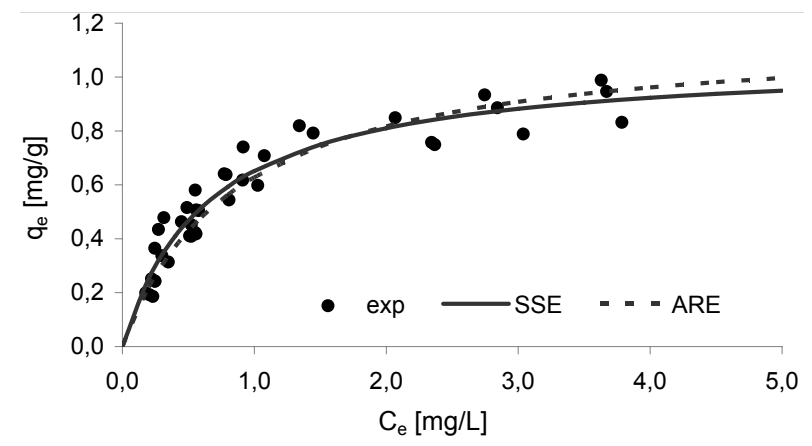

FIGURE 1. Langmuir isotherms for the sorption manganese(II) onto manganese dioxide modified chalcedonite: • experimental data, - function obtained with SSE method, "-.' function obtained with ARE method

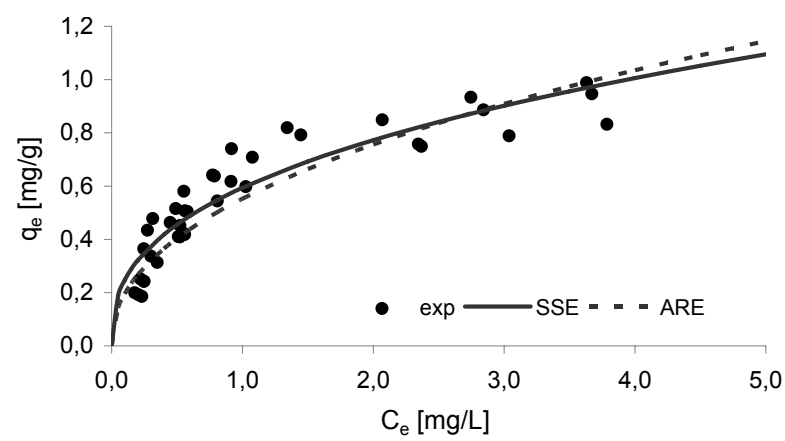

FIGURE 2. Freundlich isotherms for the sorption manganese(II) onto manganese dioxide modified chalcedonite: • experimental data, - function obtained with SSE method, -.. function obtained with ARE method 
TABLE 1. Parameters of the Langmuir's and Freundlich's equations for the sorption of manganese(II) onto manganese dioxide modified chalcedonite

\begin{tabular}{|c|c|c|c|}
\hline Langmuir's equation & $\begin{array}{c}\mathrm{q}_{\mathrm{m}} \\
\mathrm{mg} / \mathrm{g}\end{array}$ & $\begin{array}{c}\mathrm{b} \\
\mathrm{L} / \mathrm{mg}\end{array}$ & $\mathrm{r}^{2}$ \\
\hline SSE method & 1.07 & 1.55 & 0.916 \\
\hline ARE method & 1.17 & 1.16 & 0.909 \\
\hline \multirow{2}{*}{ Freundlich's equation } & $\begin{array}{c}\mathrm{K}_{\mathrm{F}} \\
\mathrm{mg}^{1-1 / \mathrm{n}} \mathrm{L}^{1 / \mathrm{n}} / \mathrm{g}\end{array}$ & - & $\mathrm{n}$ \\
\hline SSE method & 0.594 & 2.63 & - \\
\hline ARE method & 0.553 & 2.21 & 0.862 \\
\hline
\end{tabular}

described in the Langmuir isotherm equation than in the empirical Freundlich model. The determination coefficients $r^{2}$ are equal 0.916 and 0.862 , respectively. It indicates the monomolecular character of manganese(II) sorption in static conditions onto the homogeneous surface of manganese dioxide covering chalcedonite grains. In the equilibrium state the maximal sorption occurs, achieved as the saturation of the monomolecular layer by sorbate; the sorbent surface has the identical sorption energy in every active place, which is assumed in the Langmuir's theory (Langmuir 1916). The value of the maximum sorption capacity $q_{\mathrm{m}}$, calculated from the Langmuir's equation, is equal $1.07 \mathrm{mg} \mathrm{Mn} / \mathrm{g}$ MDMC (Tab. 1). Similar values of the parameters of Langmuir's equation $\left(q_{m}=1.06\right.$ $\mathrm{mg} / \mathrm{g}$ and $b=0.924 \mathrm{~L} / \mathrm{mg}$ ) were obtained in other research on the manganese(II) sorption, run in the temperature of 282 $\mathrm{K}$ and by $\mathrm{pH}=7.5$ (Michel 2008). The maximum sorption capacity of MDMC is three times higher than this determined by $\mathrm{Hu}$ et al. (2004) for manganese dioxide coated sand $\left(q_{m}=0.3805 \mathrm{mg} / \mathrm{g}\right)$. In turn, manganese oxide coated zeolite, whose maximum sorption capacity is equal $30.8 \mathrm{mg} \mathrm{Mn} / \mathrm{g}$ (Taffarel and Rubio 2010), is characterized by more higher efficiency in removing manganese(II) from water.

The equilibrium parameter $R_{L}$, defined as:

$$
R_{L}=\frac{1}{1+b C_{0}}
$$

(Han et al. 2007; Hamdaoui and Naffrechoux 2007a) can be used to predict whether a sorption system is favorable, both in static and dynamic conditions. The values of $R_{L}$, calculated on the base of constant sorption energy $b$ from the Langmuir's equation as well as an initial concentration $C_{0}$ are equal $0.123 \div 0.399$ and fall into the range $<0 ; 1>$. These results justify the conclusion that the sorption of manganese(II) on the MDMC is favorable.

The suitability of Langmuir's equation for the description of experimental data can be grounded on the fact that both of the analyzed three-parameter sorption models come down to the Langmuir's model. The empirical Redlich-Peterson isotherm equation comprises the features of Langmuir's and Freundlich's equations and assumes such a sorption model where a limitation by sorbate monolayer does not occur (Redlich and Peterson 1959). The parameter $g$ of the equation can assume values from the range $<0 ; 1>$. 
TABLE 2. Parameters of the Redlich-Peterson's and pseudo-Langmuir's equations for the sorption of manganese(II) onto manganese dioxide modified chalcedonite

\begin{tabular}{|c|c|c|c|c|}
\hline Redlich-Peterson's equation & $\begin{array}{c}\mathrm{A} \\
\mathrm{L} / \mathrm{g}\end{array}$ & $\begin{array}{c}\mathrm{B} \\
(\mathrm{L} / \mathrm{mg})^{\mathrm{g}}\end{array}$ & g & $\mathrm{r}^{2}$ \\
\hline SSE method & 1.66 & 1.55 & 1.00 & 0.916 \\
\hline ARE method & 1.35 & 1.16 & 1.00 & 0.909 \\
\hline pseudo-Langmuir's equation & $\begin{array}{c}\mathrm{q}_{\mathrm{m}} \\
\mathrm{mg} / \mathrm{g}\end{array}$ & $\begin{array}{c}\mathrm{b}_{1} \\
\mathrm{~L} / \mathrm{mg}\end{array}$ & $\begin{array}{c}\mathrm{b}_{2} \\
\mathrm{~L} / \mathrm{mg}\end{array}$ & $\begin{array}{l}\mathrm{r}^{2} \\
-\end{array}$ \\
\hline SSE method & 1.07 & 1.55 & 0.000 & 0.916 \\
\hline ARE method & 1.17 & 1.16 & 0.000 & 0.909 \\
\hline
\end{tabular}

For $g=1$, the Redlich-Peterson's equation reduces itself to the Langmuir's equation and $B=b, A=B \cdot q_{m}$ (Hamdaoui and Naffrechoux 2007b). This occurs also in the analyzed case (Tab. 2). The maximum sorption capacity $q_{m}$, calculated on this base, is equal $1.07 \mathrm{mg} \mathrm{Mn} / \mathrm{g}$ MDMC. This value coincides with the result obtained from the Langmuir's equation (Tab. 1).

Hu et al. (2004) describe a case when new sorption sites form on the surface of manganese dioxide coated sand as a result of the manganese(II) sorption. The isotherm then assumes the S-shape and the multilayer sorption is described in the pseudo-Langmuir's equation (Eq. 5), where parameters $b_{1}$ and $b_{2}$ are the sorption energy constants for the first and the second sorbate layer, respectively. The results of best-fitting of this sorption model to the experimental data are shown on the Table 2 . They prove that the manganese(II) sorption onto MDMC occurs with the creation of a single sorbate layer, because the parameter $b_{2}$ assumes the value 0 and $b_{1}$ is equal to the constant $b$ calculated from the Langmuir's equation. If a multilayer sorption of manganese(II) occurred onto MDMC, the parameter $b_{2}$ in the analyzed model would assume values greater than 0 . The calculated maximum sorption capacity $q_{m}$ has the identical value as this from the Langmuir's equation.

MDMC is a chemically active material which is characterized by the sorption and oxidation ability of manganese(II) ions. During demanganization, the material loses its properties which can be restored by regeneration with potassium permanganate (Michel 2009). It is probable that the manganese dioxide coating the surface of chalcedonite grains is reduced to oxides on a lower oxidation state as a result of the oxidation of the manganese(II) ions existing in the water being treated. The reduced oxides are neutral to the manganese(II) ions, hence a monomolecular sorbate layer forms there and the depletion of sorption properties of MDMC can be observed.

\section{CONCLUSIONS}

- Using the non-linear regression method, the best-fitting of the isotherms to the experimental data was obtained by the minimization of the sum of the squared errors, with the highest determination coefficient $r^{2}$.

- The experimental data is best described in the the Langmuir's isotherm equation. For the empirical Freundlich's 
model, the obtained determination coefficient was lower.

- The manganese(II) sorption onto manganese dioxide modified chalcedonite has a favorable character.

- According to the Langmuir's theory, a monomolecular sorbate layer forms on the surface of manganese dioxide modified chalcedonite.

\section{REFERENCES}

AL-DEGS Y., TUTUNJU M.F., SHAWABKEH R.A. 2000: The Feasibility of Using Diatomite and Mn-Diatomite for Remediation of $\mathrm{Pb}^{2+}$, $\mathrm{Cu}^{2+}$, and $\mathrm{Cd}^{2+}$ from Water. Separ. Sci. Technol. 35: 2299-2310.

AL-DEGS Y., KHRAISHEH M.A.M., TUTUNJU M.F. 2001: Sorption of lead ions on diatomite and manganese oxides modified diatomite. Water Res., 35: 3724-3728.

ALLARD S., GUNTEN U., SAHLI E., NICOLAU R., GALLARD H. 2009: Oxidation of iodide and iodine on birnessite $\left(\delta-\mathrm{MnO}_{2}\right)$ in the $\mathrm{pH}$ range 4-8. Water Res. 43: 3417-3426.

ANIELAK A.M. 2006: Właściwości fizykochemiczne klinoptylolitu modyfikowanego ditlenkiem manganu. [The physicochemical properties of manganese dioxide-modified clinoptylolite]. Przem. Chem. 85: 487-491 [Engl. summ.].

BIELAŃSKI A. 2004: Podstawy chemii nieorganicznej. Wydawnictwo Naukowe PWN, Warszawa.

BOONFUENG T., AXE L., XU Y. 2005: Properties and structure of manganese oxide-coated clay. J. Colloid Interf. Sci. 281: 80-92.

DIAS A., SA R.G., SPITALE M. C., ATHAYDE M., CIMINELLI V.S.T. 2008: Microwave-hydrothermal synthesis of nanostructured Na-birnessites and phase transformation by arsenic(III) oxidation. Materials Research Bulletin 43: 1528-1538.

DRIEHAUS W., SEITH R., JEKEL M. 1995: Oxidation of arsenate(III) with manganese oxides in water treatment. Water Research 1: 297-305.

FENG Q., KANOH H., OOI K. 1999: Manganese oxide porous crystals. J. Mater. Chem. 9: 319-333.
FREUNDLICH H.M.F. 1906: Über die adsorption in lösungen. Z. Phys. Chem. 57A: 385-470.

FRITSCH S., POST J.E., NAVROTSKY A. 1997: Energetics of low-temperature polymorphs of manganese dioxide and oxyhydroxide. Geochim. Cosmochim. Act. 13: 2613-2616.

HAMDAOUI O., NAFFRECHOUX E. 2007a: Modeling of adsorption isotherms of phenol and chlorophenols onto granular activated carbon. Part I. Two-parameter models and equations allowing determination of thermodynamic parameters. J. Hazard. Mater. 147: 381-394.

HAMDAOUI O., NAFFRECHOUX E. 2007b: Modeling of adsorption isotherms of phenol and chlorophenols onto granular activated carbon. Part II. Models with more than two parameters. J. Hazard. Mater. 147: 401-411.

HAN R., ZOU W., WANG Y., ZHU L. 2007: Removal of uranium(VI) from aqueous solutions by manganese oxide coated zeolite: discussion of adsorption isotherms and $\mathrm{pH}$ effect. Journal of Environmental Radioactivity 93: 127-143.

HO Y.S. 2006: Isotherms for the sorption of lead onto peat: comparison of linear and non-linear methods. Pol. J. Environ. Stud. 15: 81-86.

HO Y.S., CHIU W.T., WANG C.C. 2005: Regression analysis for the sorption isotherms of basic dyes on sugarcane dust. Bioresour. Technol. 96: 1285-1291.

HU P.-Y., HSIEH Y.-H., CHEN J.-C., CHANG C.-Y. 2004: Characteristics of manganese-coated sand using SEM and EDAX analysis. $J$. Colloid Interf. Sci. 272: 308-313.

KANUNGO S.B., TRIPATHY S.S., RAJEEV 2004a: Adsorption of $\mathrm{Co}, \mathrm{Ni}, \mathrm{Cu}$, and $\mathrm{Zn}$ on hydrous manganese dioxide from complex electrolyte solutions resembling sea water in major ion content. J. Colloid Interf. Sci 269: 1-10.

KANUNGO S.B., TRIPATHY S.S., MISHRA S.K., SAHOO B., RAJEEV 2004b: Adsorption of $\mathrm{Co}^{2+}, \mathrm{Ni}^{2+}, \mathrm{Cu}^{2+}$, and $\mathrm{Zn}^{2+}$ onto amorphous hydrous manganese dioxide from simple (1-1) electrolyte solutions. J. Colloid Interf. Sci 269: $11-21$.

KOULOURIS G. 1995: Dynamic studies on sorption characteristics of ${ }^{226} \mathrm{Ra}$ on manganese dioxide. Journal of Radioanalytical and Nuclear Chemistry 2: 269-279.

KOWAL A.L., ŚWIDERSKA-BRÓŻ M. 2009: Oczyszczanie wody. Podstawy teoretyczneitechnologiczne, procesy i urządzenia. Wydawnictwo Naukowe PWN, Warszawa 2009. 
LANGMUIR I. 1916: The constitution and fundamental properties of solids and liquids. J. Am. Chem. Soc. 38: 2221-2295.

LEE C.-I, YANG W.-F, HSIEH C.-I 2004: Removal of copper(II) by manganese-coated sand in a liquid fluidized-bed reactor. J. Hazard. Mater. B 114: 45-51.

MA S.-B., AHN K.-Y., LEE E.-S., OH K.-H., KIM K.-B. 2007: Synthesis and characterization of manganese dioxide spontaneously coated on carbon nanotubes. Carbon. 45: 375-382.

MALIYEKKAL S.M., SHARMA A.K., PHILIP L. 2006: Manganese-oxide-coated alumina: A promising sorbent for defluoridation of water. Water Res. 40: 3497-3506.

MICHEL M.M. 2008: Usuwanie jonów manganu(II) z roztworów wodnych na chalcedonicie naturalnym i modyfikowanym. [Removal of manganese(II) from aqueous solution by natural and modified chalcedonite]. Materials of VIII ${ }^{\text {Th }}$ International Conference ,Water Supply and Water Quality" Poznań-Gniezno, Poland, T. 1, p. 557-569 [Engl. summ.].

MICHEL M.M. 2009: Odmanganianie wody podziemnej na modyfikowanym chalcedonicie. Gaz, Woda i Technika Sanitarna 4: 22-26.

MICHEL M.M. 2011: Charakterystyka chalcedonitu ze złoża Teofilów pod kątem możliwości wykorzystania w technologii uzdatniania wody i oczyszczania ścieków. [Characteristics of chalcedonite from Teofilów deposit for possible use in technology of water and wastewater treatment]. Gospodarka Surowcami Mineralnymi 27: 49-67 [Engl. summ.].

MICHEL M.M., KIEDRYŃSKA L., TYSZKO E. 2008: Badania skuteczności odmanganiania wody podziemnej na modyfikowanym chalcedonicie i masie katalitycznej Purolite MZ-10. [Manganese removal from groundwater on modified chalcedonite and Purolite MZ-10 beds]. Ochrona Środowiska 3: 15-20 [Engl. summ.].

MOORE W.S., REID D.F. 1973: Extraction of radium from natural waters using manganese - impregnated acrylic fibers. J. Geophysical Res. 36: 8880-8886.

MURRAY J.W. 1974: The surface chemistry of hydrous manganese dioxide. J. Colloid Interf. Sci. 3: 357-371.

OLAŃCZUK-NEYMAN K. 2001: Mikroorganizmy w kształtowaniu jakości i uzdatnianiu wód podziemnych. Monografie Komitetu Inżynierii
Środowiska PAN, Vol. 1, Wydawnictwo Politechniki Gdańskiej, Gdańsk.

PIECH A. 2007: Wykorzystanie diatomitów karpackich modyfikowanych powierzchniowo do usuwania arsenu $\mathrm{z}$ roztworów wodnych. [Utilisation of surface modified carpathian diatomites for arsenic removal from aqueous solution]. Zesz. Nauk. Politechniki Rzeszowskiej, Budownictwo i Inżynieria Środowiska 241: 49-56 [Engl. summ.].

RAJE N., SWAIN K.K. 2002: Purification of arsenic contaminated ground water using hydrated manganese dioxide. Journal of Radioanalitical and Nuclear Chemistry 1: 77-80.

RATAJCZAK T., WYSZOMIRSKI P. 1991: Charakterystyka mineralogiczno-surowcowa chalcedonitów spongiolitowych $\mathrm{z}$ Teofilowa nad Pilica. [Mineralogical and technological characteristics of spongolithic chalcedonite of Teofilów on Pilica]. Gospodarka Surowcami Mineralnymi 7: 65-84 [Engl. summ.].

REDLICH O., PETERSON D.L. 1959: A useful adsorption isotherm. J. Phys. Chem. 63: 1024-1026.

SALARIRAD M.M., BEHNAMFARD A. 2011: Modeling of equilibrium data for free cyanide adsorption onto activated carbon by linear and non-linear regression methods. International Conference on Environment and Industrial Innovation, IPCBEE vol.12 (2011) (C) IACSIT Press, Singapore.

SU Q., PAN B., PAN B., ZHANG Q., ZHANG W., LV L., WANG X., WU J., ZHANG Q. 2009: Fabrication of polymer-supported nanosized hydrous manganese dioxide (HMO) for enhanced lead removal from waters. Science of the Total Environment 407: 5471-5477.

ŚWIĄTCZAK J., SKOTAK K., BRATKOWSKI J., WITCZAK S., POSTAWA A. 2008: Metale i substancje towarzyszące w wodach przeznaczonych od spożycia w Polsce. [Metals and related substances in drinking waters in Poland]. Materials of VIIIth International Conference ,Water Supply and Water Quality" Poznań-Gniezno, Poland, T. 1, p. 289-301 [Engl. summ.].

TAFFAREL S.R., RUBIO J. 2010: Removal of $\mathrm{Mn}^{2+}$ from aqueous solution by manganese oxide coated zeolite. Minerals Engineering 23: 1131-1138.

TRIPATHY S.S., BERSILLON J.-L., GOPAL K. 2006: Adsorption of $\mathrm{Cd}^{2+}$ on hydrous manga- 
nese dioxide from aqueous solutions. Desalination 194: 11-21.

Streszczenie: Modelowanie sorpcji manganu(II) na chalcedonicie modyfikowanym tlenkiem manganu(IV) metoda regresji nieliniowej. Tlenek manganu(IV) charakteryzuje się powierzchnią o charakterze kwasowym i wysokiej wartości ujemnego ładunku powierzchniowego. Posiada właściwości sorpcyjne i oksydacyjne w stosunku do takich zanieczyszczeń, jak metale ciężkie, radionuklidy, arsenian(III), chromian(III). W technologii uzdatniania wody jest stosowany jako pokrycie złóż odmanganiających. Tlenek manganu(IV) jest stosowany do modyfikacji różnych materiałów, w tym chalcedonitu, który był przedmiotem badań prezentowanych w tej pracy. Sorpcja równowagowa manganu(II) była modelowana metodą regresji nieliniowej przy użyciu równań izoterm Langmuira, Freundlicha, Redlicha-Petersona oraz pseudo-Langmuira. Wyznaczanie parametrów równań izoterm prowadzono dwoma sposobami: poprzez minimalizację sumy kwadratów błędów bezwzględnych oraz minimalizację średniego błędu względnego. Dane eksperymentalne były najlepiej opisywane przez równanie izotermy Langmuira, przy współczynniku determinacji $r^{2}=0,916$. Obliczone parametry równania wynosiły: $q_{m}=1,07$ $\mathrm{mg} / \mathrm{g}$ i $b=1,55 \mathrm{~L} / \mathrm{mg}$. Trójparametrowe równania Redlicha-Petersona i pseudo-Langmuira, zakładające możliwość sorpcji wielowarstwowej, sprowadzały się do równania Langmuira. Potwierdza to monowarstwową sorpcję manganu(II) na chalcedonicie modyfikowanym tlenkiem manganu(IV).

Stowa kluczowe: sorpcja, mangan, tlenek manganu(IV), chalcedonit modyfikowany, metoda regresji nieliniowej.

\section{MS. received October 2011}

\section{Authors' address:}

Magdalena M. Michel

Lidia Kiedryńska

Wydział Budownictwa i Inżynierii Środowiska

Katedra Inżynierii Budowlanej

Szkoła Główna Gospodarstwa Wiejskiego

ul. Nowoursynowska 159

02-776 Warszawa

e-mail:magdalena_michel@sggw.pl

lidia_kiedrynska@sggw.pl 